\title{
TOP2B Gene
}

National Cancer Institute

\section{Source}

National Cancer Institute. TOP2B Gene. NCI Thesaurus. Code C26593.

This gene is involved in chromosome recombination, DNA replication and the regulation of DNA topology during transcription. 